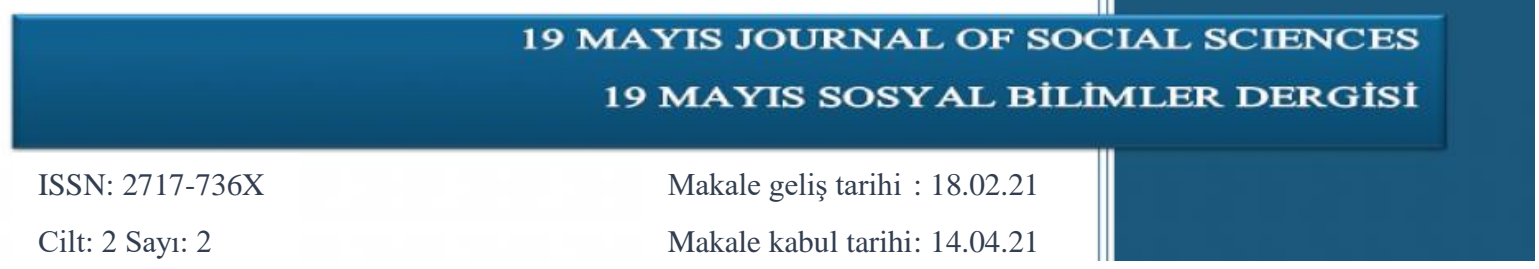

\title{
EXPERIMENTING BLENDED LEARNING MODEL USING AN AUGMENTED REALITY-BASED GAME
}

\author{
Antonius SURATNO \\ Soegijapranata Catholic University \\ English Department, Faculty of Language and Arts, Semarang, Indonesia \\ a.suratno@unika.ac.id
}

ORCID: 0000-0002-3727-0368

Erdhi Widyarto NUGROHO

Soegijapranata Catholic University

Information System Department, Faculty of Computer Science, Semarang, Indonesia.

ORCID: 0000-0002-4270-9021

\begin{abstract}
Augmented Reality (AR) is a cutting-edge technology used for various learning media including for English learning. The advantage of AR in teaching is its ability to add multimedia objects to traditional teaching materials that motivate students to learn. The purpose of the study was to experiment with the use of AR-based game as additional material to the face-to-face teaching and learning in the blended learning model to improve English reading skills in secondary schools. This study deployed a quasi-experimental method based on a statistical analysis of the pre-test and post-test design. The whole research project involved a questionnaire and Focus Group Discussion (FGD) data collection yet to be reported here. The experiment results of correlation test score respectively showed Pair $1=.406$ at the significance level of 0.17 ; Pair $2=.288$ at the significance level of 0.99 , and Pair $3=.030$ at the significance level of 8.86 , while the results of the Paired Sample Test' showed the value of "Paired Differences" of -5.569. This value indicated the difference between the pre-test and post-test results with a difference between -6,674 to 4,464 at the $95 \%$ confidence interval. The results of this experiment rejected hypothesis 0 which suggests that as the ArReadSpeed game is combined with teaching in the context of classroom learning resulted in good learning outcomes, making it a good blended learning model. The results of this experiment confirmed that the use of AR-based games for blended-learning contexts is an appropriate learning model. Due to the ever advancing technology and the current and future learning environment, this study brings an
\end{abstract}


implication for current and future education practitioners to consider incorporating games into the teaching of English skills in the context of blended learning in response to the change in learners' styles of learning.

Keywords: augmented reality, learning media, blended-learning, reading English

\section{Introduction}

Among the efforts to understand how cellular technology is related to innovative ways of teaching and learning that attend to technological advances provide opportunities for the application of mobile learning in a very wide spectrum of learning activities (Naismith et al., 2004; Kukulska-Hulme \& Traxler, 2007). Developed countries have adopted Augmented Reality (AR) technology as part of the mobile game which has many advantages for the learning process because of its increasingly adaptive nature. In fact, Indonesian educators and ICT experts have been able to develop AR technology. Unfortunately, this technology has not been much exploited in Indonesian schools. AR technology is a streaming computing technology capable of mediating reality through a combination of real and virtual world. It is able to recognise objects appearing in the video from which virtual objects can be inserted at a suitable position. Through that way, the users may get involved with the virtual objects inside the video relevant to the predesigned activities. What is more, this technology is able to add to or remove from images that results in an augmented reality.

Technological developments also provide opportunities to improve English language skills. Previous research conducted by (Suratno \& Aydawati, 2016) showed that students' perceptions of the presence of technology in the world of language learning showed a positive perception and respondents believed that the existence of technological devices would be able to increase interest in learning English. AR has been applied to various fields such as entertainment, arts, commerce, and others. One of them that fits the context of this research is AR for learning. AR's role in teaching is in its ability to add multimedia objects to traditional teaching materials such as textbooks, flashcards, or textbooks. AR combined with mobile gadgets technology such as a cell-phone or tablet PC allows students to interact with figures or learning objects displayed by machines.

The results of research by Klopfer \& Squir (2008) and Luckin \& Stanton Fraser (2011) show that the use of AR for educational purposes can arouse students' learning interest and increase motivation and engagement. Luckin \& Stanton Fraser (2011) in their latest research found that the use of AR supports certain learning activities, such as problemsolving, in a very interactive and easy-to-remember way, in addition to the presence of other positive aspects such as being flexible, fun, and easy to use because of its visual and mobile characteristics. Besides, Cowan and Butler (2013) reported that with AR technology, students' performance in the field of Geography showed significant 
improvement. The role of AR in improving certain skills has also been reported in the research of Martin-Gutierrez et al. (2010) and Schmalstieg \& Wagner (2007). Subsequent research has shown AR has a positive effect on learning and processes directly related to learning, as reported by Luckin \& Stanton-Fraser (2011). They conclude that there has been an increase in memory and engagement skills, both of which are key to effective learning success, while Di Serio et. al. (2012) found that statistically, the use of AR could significantly increase the motivation of high school students.

\section{AR and learning}

One of the highlights of $\mathrm{AR}$ is its adaptive nature to the surrounding environment and the way information can be extracted from that environment which allows us to learn about what can be found there and provides information about what is relevant to it (FitzGerald, et al., 2013). AR is a real-time streaming computing technology that combines real and virtual reality called augmented reality. The ability to recognize objects in the video makes it possible to insert virtual objects into suitable positions. An important aspect of $\mathrm{AR}$ is the dialogue between the media and the context in which AR is used, namely how the media responds and changes the context into a mixture that can be used to learn according to the desired design.

Neuburger, et al. (2018) stated that AR is an example of a cutting-edge technology that has an impact on direct perception because both have the power to unify one's perception of real space and virtual reality. Simulated by the computer in a way that resembles a reallife environment, this technology provides users with interactive nature of learning. Because of its nature, it makes it very easy to display objects that were previously difficult to present in the classroom. The combination of reality and virtuality makes the things that were impossible in the past now possible. Through technology facilitation, users can interact with virtual objects in the video, relevant to predetermined activities. Thus, this technology is suitable for mediating learning, and over time students can make use of it through various cellular gadgets.

\section{Game and blended learning}

State of the art research in the field of technology and language teaching in the last decade has recommended the importance of technology for teaching and learning activities, especially in improving their quality (Lehtinen, 2008). One way is to integrate games into the blended-learning model, where technology is incorporated into the previously known as the traditional model of face-to-face teaching and learning, to complement or add to the material taught in the classroom. With the potential of fered by technological advances today, every stakeholder in language learning and teaching is expected to get involved in increasing students' learning participation in the information networks where knowledge is an important source of information for social and economic progress (Lehtinen, 2008). One way is to innovate out of the technological advancement which is increasingly rich in learning potentials that can be explored for the best of education. 
Games are often associated with fun and entertaining activities. Other studies consistently show evidence that learning by playing games minimizes the time it takes to respond to stimuli, improves hand-eye coordination skills, and finally increases students' self-esteem (Griffits, et.al., 2012) so that games have a role beyond the purpose of the game itself. Later on, Lucardie (2014) believes that apart from functioning as a means of entertainment, games will play an important role in learning but only if they are designed in such a way to answer certain problems or to teach certain skills. Games are also great for a variety of purposes, including language learning. Therefore, it can be concluded that a well-designed game can create the preconditions and prerequisites for a better learning process.

Due to its nature, AR-based game may open up opportunities for students to learn independently and enrich a learning experience that is not confined by time and space. Thus, it helps to overcome the constraints of the lack of students' quality learning as a result of high-class occupancy and limited class hours. Moreover, currently, the Indonesian government is on the move to welcome the era of Education 4.0 (Waras, 2018). The increasing interest in learning is believed to boost the quality of human resources and therefore the researchers intend to respond to it by experimentation with combining classroom learning and AR-based game in the blended-learning model.

The question raised is whether the combination of traditional teaching and extra time playing AR-based game improve secondary school students' reading skills? Therefore, this study is aimed at finding out if the blended model design that combines traditional teaching of reading and the experience of playing a game based on augmented reality can produce better learning, especially to help secondary school students to improve English reading skills.

\section{Method}

\section{Research Model}

The purpose of this research is to experiment with an AR game in the context of blended learning to help students learn English reading skills in secondary schools. This research is carried out in a quasi-experimental design that compares two control groups, one playing an AR game and a group learning to read in a traditional classroom context without playing the AR game. Then, the two groups altogether are compared to an experimental group taught in a traditional context and then asked to play a game. Such an experiment is meant to see if there is a difference in the results of learning between the compared groups. Data generated from this research are the scores of students taken from the pre and post-tests. Due to the nature of the research and the purpose of the study, a purely quantitative approach was chosen to treat and analyze the data.

\section{Participants}


This research activity involved 102 high school students participating in the experiment. In the original plan, students were selected purposively from 5 secondary schools in the city of Semarang to get involved in the data collection. Efforts to stick to the original plan were made by asking permission from several high school principals. However, the unfortunate situation caused by a prolonged Covid-19 outbreak has made this research activity not fully implemented as planned. Of the 5 secondary schools previously projected to be involved, only 2 schools granted permission to conduct research. There are various obstacles to this refusal. In the case of public schools, researchers were constrained by a very long licensing process because for a school to be used as a research site, they must obtain permission from the municipality officers before the school can issue a permit. One public school and one private school that were visited for negotiation of the research participation eventually constrained by the lack of distance learning facilities and the absence of internet access, while the research itself had to be carried out remotely. One public school previously granting permission finally refused to be involved. As a result, of all 200 students involved in this study, only 102 were involved in the experiment and survey, and the remaining 98 students were only asked to contribute to the questionnaire data collection and were dropped from the experiment. They are the $7^{\text {th }}$ and $8^{\text {th }}$-grade students of secondary school. The reason for choosing this class is because they have not prepared for the final school exams. Considering the limited time for data collection, the interview that was originally planned after the experiment failed to be carried out. Instead, the FGD involving English teachers, management officials, and school students even though it was in an unusual format, namely a virtual FGD through a Video Conference was held. The interview and FGD results are to be reported separately.

\section{Data Collection}

The instruments used in this research were two sets of the pre-validated virtual reading comprehension test sheets for pre and post-tests, reading comprehension materials sheets for classroom teaching and exercises, test results sheets, and an AR-game consisting of reading quizzes for gameplay. Validation sheets were used to obtain product validity prior to the implementation of the experiment to determine the suitability of the test materials with the students' grade and difficulty level which were confirmed by the English subject teachers involved in the experiment. All instruments were valid and reliable before use. The reading quizzes contained 5 to 6 passages with a total of 25 questions designed for comprehension and the test types were multiple-choice tests containing 4 options for each individual answer.

\section{Procedure}

The stages include: 1) needs analysis of student, content, structure, and instructional goals to align with the experiment objectives to be achieved, 2) Selection of participants which include schools, number of students, students' grades. 3) designing research instruments 
in the forms of reading materials for pre and post-test, and AR-game which had previously been successfully tried out, 4) developing teaching materials for reading comprehension lesson and PowerPoint presentation, and reading exercise, 5) validating the pre-and posttests via small group test trial and English subject teachers to match the test materials with the school curriculum and the appropriate level of difficulty as well as for validating the instruments for the practicality of implementation through lecturer and students, 6) setting up all materials of test and teaching materials, and game on the school distance learning platform on the appropriate schedules, 7) implementing procedures of experiment and data analysis.

\section{Data Analysis}

The following table describes the 3 groups simultaneously describing the stages that each group went through.

\begin{tabular}{|c|l|l|l|}
\hline Stages & Control Group A & Control Group B & \multicolumn{1}{|c|}{$\begin{array}{c}\text { Full Experiment } \\
\text { Group C }\end{array}$} \\
\hline I & Pre-Test & Pre-Test & Pre-Test \\
\hline II & Reading class & $\begin{array}{l}\text { Playing } \\
\text { ArReadSpeed game }\end{array}$ & Reading class \\
\hline III & Post-Test & Post-Test & $\begin{array}{l}\text { PlayingArReadSpeed } \\
\text { game }\end{array}$ \\
\hline IV & - & - & Post-Test \\
\hline
\end{tabular}

As seen in the table above, 2 control groups A and B are treated differently, where group A followed the procedure of Pre-Test, ArReadSpeed game played and ended up with the Post-Test, while group B was given treatment by attending virtual face-to-face reading comprehension teaching and practices only without ArSpeedRead gameplay. The full experiment group, namely group $\mathrm{C}$, took all the stages to find out whether by being taught reading material in class and then playing a game, they showed a difference in terms of their post-test results. The research was so-designed because this study was on the assumption that the Full Experiment Group should show better results than the two groups and that AR-based game as it is combined with classroom teaching has the potential to help better learning (see hypothesis). The following section describes the experiment results.

\section{Results}

\section{Experiment}


Given the nature of the research design, the analysis is merely based on the experimental data. Paired-t-test was employed to perform statistical tests by comparing experimental variables involving 3 different groups. Tests were carried out to compare the Pre-Test and Post-Test results of the entire experiment participants to find out whether there was a difference between the Pre-Test and Post-Test results and if the difference is statistically significant. Then, a separate test was carried out for 3 groups to find out if the experimental results reject or accept $\mathrm{H} 0$ and refuse Ha. To prove that the difference is not simply a coincidence, the 0.05 significance level was used in the Paired Samples Correlation test. In determining the test results of the paired-t-test, criteria are set as follows:

1. If the Sig. (2-tailed) $<0.05$, then $\mathrm{HO}$ is rejected and $\mathrm{Ha}$ is accepted.

2. Conversely, if the Sig. (2-tailed)> 0.05, then H0 is accepted and Ha is rejected.

Hypothesis $\mathrm{HO}$ states that there is no mean difference between the results of the pre-test and post-test, which means that there is no effect of reading classroom teaching combined with playing games in improving student reading comprehension as indicated by the posttest scores.

The hypothesis Ha states that there is a mean difference between the Pre-Test and PostTest results, which means that there is an effect of reading classroom teaching combined with playing games in improving student reading comprehension as indicated by the posttest scores.

It should be noted that this experiment was carried out during the Covid-19 pandemic, so there were obstacles in implementing face-to-face teaching and learning activities as one of the prerequisites for blended learning. Due to this obstacle, the notion of face-to-face learning was modified in such a way utilizing virtual face-to-face encounters to create a similar face-to-face learning atmosphere. Aside from that, the experiment that involved students playing the ArReadSpeed game, originally based on a board game, was also constrained because the actual board game could not be modified into a virtual format. Even so, the expected mode of gameplay could be naturally maintained. Quantitative analysis of the questionnaire which contained respondents' views on the potential, advantages, readiness, and prospects of AR game for learning to support this experiment and to obtain answers to the question of whether the game designed and tested is appropriate for blended learning context is to be reported separately.

Experiment results 
In the following section, a summary of the results of descriptive statistical tests on the sample studied is presented, namely the pre-test and post-test for a total of 102 respondents. Tests were carried out by deploying a paired-t-test for the overall results of the pre-test data. However, because the paired-t-test statistical test requires normality of data, the following test procedure was taken.

Down below are the results of the normality test of the Pre-Test value data.

Table 1: Pre-test normality data

Tests of Normality

\begin{tabular}{|l|l|l|l|l|l|l|l|}
\hline & \multirow{2}{*}{} & \multicolumn{3}{|l|}{ Kolmogorov-Smirnov } & \multicolumn{3}{l|}{ Shapiro-Wilk } \\
\cline { 3 - 8 } & Grouping & Statistic & Df & Sig. & Statistic & Df & Sig. \\
\hline $\begin{array}{l}\text { Pre-test } \\
\text { Result }\end{array}$ & $\begin{array}{l}\text { Con- } \\
\text { group }\end{array}$ & .151 & 34 & .048 & .939 & 34 & .058 \\
& $\begin{array}{l}\text { Exp-game } \\
\end{array}$ & .122 & 34 & $.200 *$ & .942 & 34 & .069 \\
& $\begin{array}{l}\text { FullEx- } \\
\text { group }\end{array}$ & .139 & 34 & .092 & .929 & 34 & .029 \\
\hline
\end{tabular}

*. This is a lower bound of the true significance.

Normality test using Kolmogorov Smirnov and Shapiro Wilk show that the pre-test data are normally distributed because the statistical test results are at a significance level which is greater than 0.05, Below is the overall look of the results as presented on a histogram of the control group and P-P Plot of the experiment group.

Figure 1: Histogram of the Control Group normality test 


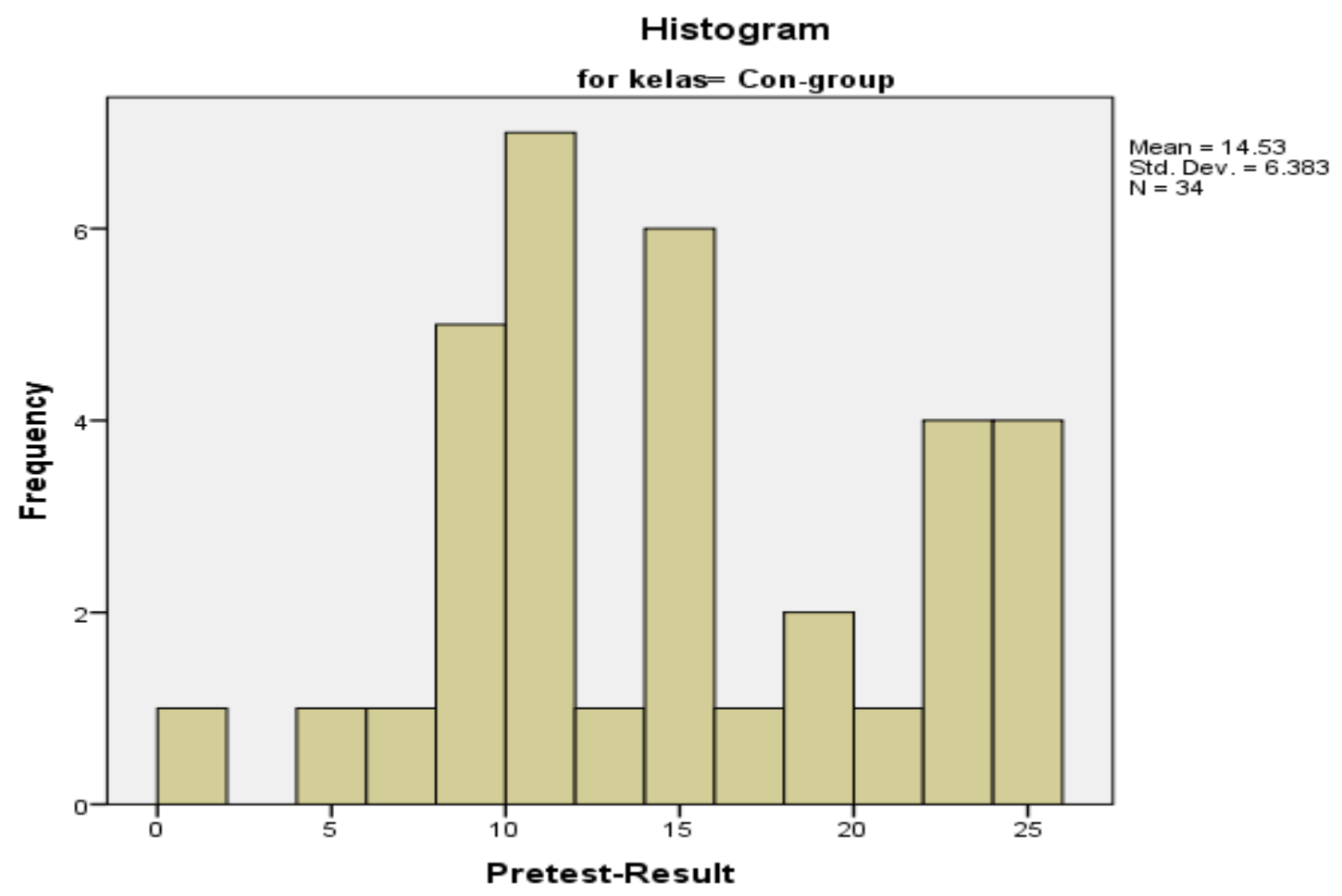

From the histogram above, it can be seen that the scores of the two groups to be compared in this research normally distributed making them readily further examined statistically in a paired-t test as reported down below.

Figure 2: The P-P Plot of the Experiment Group normality test 


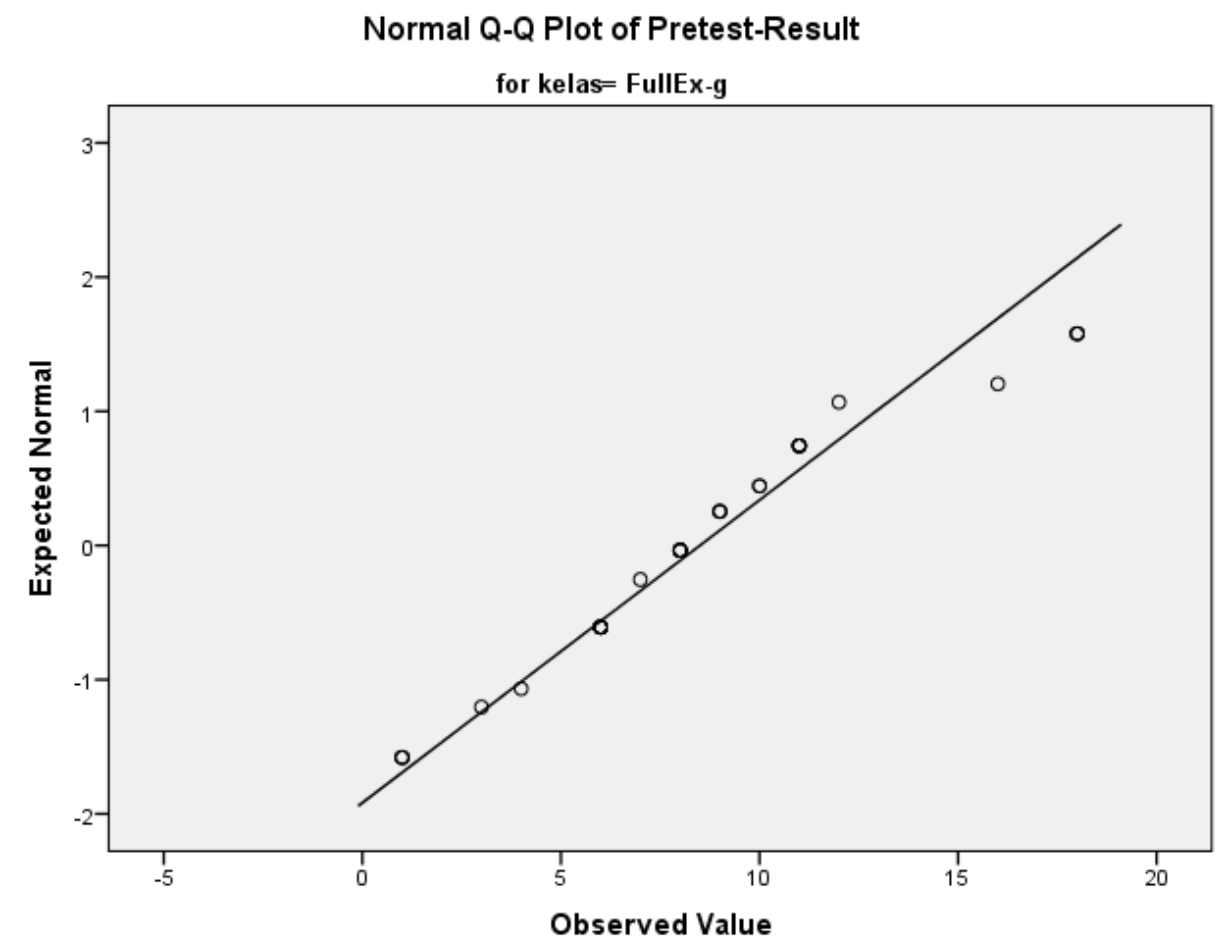

The P-P Plot above shows that the distribution of the dots is close to the diagonal line, it can be concluded that the residual data of this study is normally distributed. This means that the normality test is fulfilled making them readily further examined statistically in a paired-t test below.

\section{Post-test normality test results}

The following are the results.

Table 3: Post-test Normality data

Tests of Normality

\begin{tabular}{|l|l|l|l|l|l|l|l|}
\hline & \multirow{2}{*}{} & & \multicolumn{3}{|l|}{ Kolmogorov-Smirnov } & \multicolumn{3}{l|}{ Shapiro-Wilk } \\
\cline { 3 - 8 } & Grouping & Statistic & $\mathrm{df}$ & Sig. & Statistic & df & Sig. \\
\hline Post-test & Con-group & .187 & 34 & .004 & .900 & 34 & .005 \\
Result & Exp-game & .215 & 34 & .000 & .928 & 34 & .028 \\
& $\begin{array}{l}\text { FullEx- } \\
\text { group }\end{array}$ & .160 & 34 & .028 & .968 & 34 & .400 \\
\hline
\end{tabular}

a. Lilliefors Significance Correction 
Unlike the results of the pre-test, the normality data of the post-test contained two groups that were not normally distributed, namely Con-Group and Ex-Game in the Kolmogorov Smirnov test, each with the results smaller than the value of 0.05 , respectively 0.04 and 0.00. FullEx-Group test result was normally distributed at the value of 0.28. However, when tested with Shapiro-Wilk, the data for the three groups were normally distributed because the statistical tests for the three groups were at a significance level equal to or greater than 0.05 .

\section{Paired-t-test results}

Table 4: The difference between pre and post-tests

Paired Samples Statistic

\begin{tabular}{|r|l|l|l|l|}
\hline & Mean & $\mathrm{N}$ & $\begin{array}{l}\text { Std. } \\
\text { Deviation }\end{array}$ & $\begin{array}{l}\text { Std. Error } \\
\text { Mean }\end{array}$ \\
\hline Pair 1 Pre-test & 12.97 & 102 & 6.314 & .625 \\
Post-test & 18.54 & 102 & 3.751 & .371 \\
\hline
\end{tabular}

Table 4 presents the descriptive statistic results of both pre-test and post-test data. For the pre-test, the mean value of the results is 12.97 . Meanwhile, the post-test mean value is 18.54, with a standard deviation of 6.314 and 3.751, with a mean standard error of .625 and .371 respectively. Because descriptively the pre-test mean value of 12.97 is smaller than the average post-test result of 18.54, the difference between them is self-explanatory. When the pre and post-test results are compared, the results show a strong correlation as evidenced by the correlation value $\mathrm{r} .470$ as shown in the correlation test results in Table 5 below.

Table 5: Correlation of the Paired samples

\section{Paired Samples Correlations}

\begin{tabular}{|l|l|l|l|}
\hline & $\mathrm{N}$ & Correlation & Sig. \\
\hline $\begin{array}{r}\text { Pair 1 Pre-test Result \& } \\
\text { Post-test Result }\end{array}$ & 102 & .470 & .000 \\
\hline
\end{tabular}

The obtained correlation score is .470 at a significance level of 0.00 which is smaller than 0.05 , it can be stated that there is a strong correlation between the Pre-Test and Post-Test results. 


\section{Significance of the paired differences}

Table 6: Significance of the Paired differences

Paired Samples Test

\begin{tabular}{|c|c|c|c|c|c|c|c|c|c|}
\hline & & \multicolumn{5}{|c|}{ Paired Differences } & \multirow[b]{3}{*}{$\mathrm{t}$} & \multirow[b]{3}{*}{ df } & \multirow{3}{*}{$\begin{array}{l}\text { Sig. } \\
(2- \\
\text { tailed })\end{array}$} \\
\hline & & \multirow{2}{*}{$\begin{array}{c}\text { Mea } \\
\mathrm{n}\end{array}$} & \multirow{2}{*}{$\begin{array}{c}\text { Std. } \\
\text { Deviatio } \\
\mathrm{n}\end{array}$} & \multirow{2}{*}{$\begin{array}{l}\text { Std. } \\
\text { Error } \\
\text { Mean }\end{array}$} & \multicolumn{2}{|c|}{$\begin{array}{c}95 \% \\
\text { Confidence } \\
\text { Interval of the } \\
\text { Difference }\end{array}$} & & & \\
\hline & & & & & Lower & Upper & & & \\
\hline $\begin{array}{l}\text { Pair } \\
1\end{array}$ & $\begin{array}{l}\text { Pre-test } \\
\text { Result - } \\
\text { Post-test } \\
\text { Result }\end{array}$ & $\begin{array}{r}- \\
5.56 \\
9\end{array}$ & 5.626 & .557 & -6.674 & -4.464 & -9.996 & 101 & .000 \\
\hline
\end{tabular}

Having identified the correlation of the data, the significance of the paired differences need to be established. Based on the Paired Sample Test above, the value of Paired Differences is $-5,569$. This value shows the difference between the Pre-Test and Post-Test results with a difference between $-6,674$ to $-4,464$ at the $95 \%$ confidence interval. However, because this experiment involved three different groups, this hypothesis still has to be retested based on the results of each group. It has to be so to prove that the experimental group indeed shows better results than the control groups and that the AR game has a role in improving students' learning outcomes, in this case, reading comprehension score.

Results of the 3 groups Paired-t-test

The section to come reports the descriptive outlook of the pre and post-test scores mean difference (Table 7), the results of the paired-t-test involving the three groups (Table 8), and the confidence level of the differences (Table 9) where group 1 is the control group which only plays a game without teaching reading treatment, group 2 is the control group which is only given treatment for teaching reading without playing a game, and group 3 is the experimental group which was treated with both the teaching of reading comprehension and playing a game. 


\section{A comparative outlook of the 2 groups}

Tabel 7: The comparative look of the 3 group means

Paired Samples Statistic

\begin{tabular}{|c|c|c|c|c|c|}
\hline & & Mean & $\mathrm{N}$ & $\begin{array}{c}\text { Std. } \\
\text { Deviation }\end{array}$ & $\begin{array}{l}\text { Std. Error } \\
\text { Mean }\end{array}$ \\
\hline \multirow[t]{2}{*}{ Pair 1} & PreConG & 14.53 & 34 & 6.383 & 1.095 \\
\hline & PostConG & 19.44 & 34 & 3.653 & .626 \\
\hline \multirow[t]{2}{*}{ Pair 2} & PreExGameG & 15.88 & 34 & 5.459 & .936 \\
\hline & PostExGameG & 17.41 & 34 & 3.560 & .611 \\
\hline \multirow[t]{2}{*}{ Pair 3} & PreFulExG & 8.50 & 34 & 4.433 & .760 \\
\hline & PostFulExG & 18.76 & 34 & 3.854 & .661 \\
\hline
\end{tabular}

Table 7 above shows the test scores mean difference between the pre-test and post-test in each group, subsequently with their standard deviation value. Of the three groups tested, each shows differences where all the post-tests show a higher mean value, which means that irrespective of the group and the treatment, each group scores higher in the post-test. Apart from Pair 1, the pre-test standard deviation is relatively high showing that the scores are more varied.

\section{A comparative outlook of the paired samples correlation}

Table 8: Comparative look of the Paired samples correlation

Paired Samples Correlations

\begin{tabular}{|ll|r|r|r|}
\hline & $\mathrm{N}$ & \multicolumn{1}{c|}{$\begin{array}{c}\text { Correlatio } \\
\mathrm{n}\end{array}$} & \multicolumn{1}{c|}{ Sig. } \\
\hline Pair 1 & $\begin{array}{l}\text { PreConG \& PostConG } \\
\text { Pair 2 }\end{array}$ & 34 & .406 & .017 \\
$\begin{array}{l}\text { PreExGameG } \\
\text { PostExGameG }\end{array}$ & $\&$ & 34 & .288 & .099 \\
Pair 3 $\begin{array}{l}\text { PreFulExG } \\
\text { PostFulExG }\end{array}$ & $\&$ & 34 & .030 & .866 \\
\hline
\end{tabular}

After the paired samples for the three groups were tested, a further step was looking at whether there is a correlation between the pre-test and post-test in the three groups, Table 8 above shows that there is a significant correlation between the result of the pre and posttests. The results of the correlation test subsequently show the following: Pair $1=.406$ at the significance level of 0.17 ; Pair $2=.288$ at the significance value 0.99 'and Pair $3=$ .030 at the significance value 8.86. The following are the Paired Sample Test data. 
Table 9: Significance level of the Paired Samples

\begin{tabular}{|c|c|c|c|c|c|c|c|c|c|}
\hline \multicolumn{10}{|c|}{ Paired Samples Test } \\
\hline & & \multicolumn{5}{|c|}{ Paired Differences } & \multirow[b]{3}{*}{$\mathrm{t}$} & \multirow[b]{3}{*}{ df } & \multirow{3}{*}{$\begin{array}{l}\text { Sig. } \\
(2- \\
\text { tailed })\end{array}$} \\
\hline & & \multirow[b]{2}{*}{ Mean } & \multirow{2}{*}{$\begin{array}{l}\text { Std. } \\
\text { Deviat } \\
\text { ion }\end{array}$} & \multirow{2}{*}{$\begin{array}{l}\text { Std. } \\
\text { Error } \\
\text { Mean }\end{array}$} & \multicolumn{2}{|c|}{$\begin{array}{c}95 \% \\
\text { Confidence } \\
\text { Interval of the } \\
\text { Difference }\end{array}$} & & & \\
\hline & & & & & Lower & Upper & & & \\
\hline Pair & PreConG & & & & & & & & \\
\hline 1 & PostConG & -4.912 & 5.931 & 1.017 & -6.981 & -2.842 & $\begin{array}{r}4.82 \\
9\end{array}$ & 33 & .000 \\
\hline Pair & PreExGameG & & & & & & & & \\
\hline 2 & $\begin{array}{l}- \\
\text { PostExGame } \\
\text { G }\end{array}$ & -1.529 & 5.593 & .959 & -3.481 & .422 & $\begin{array}{r}1.59 \\
4\end{array}$ & 33 & .120 \\
\hline $\begin{array}{l}\text { Pair } \\
3\end{array}$ & $\begin{array}{l}\text { PreFulExG } \\
\text { PostFulExG }\end{array}$ & $\begin{array}{r}- \\
10.265\end{array}$ & 5.786 & .992 & $12.283^{-}$ & -8.246 & $\begin{array}{r}- \\
10.3 \\
45\end{array}$ & 33 & .000 \\
\hline
\end{tabular}

More specifically, Table 9 of the Paired Sample Test above respectively shows the mean values of $-4,912,-1,529$, and $-10,265$. This value shows the difference between the results of the pre-test and the post-test with the difference between 3 and 10 at the level of $95 \%$ confidence of interval difference. So it can be confidently stated that all three pairs have a strong correlation. The result cannot be used as the basis to claim that game treatment only has a better effect than treatment for reading lessons only. It is necessary to carry out another experiment involving a group with a larger number of participants. However, an interesting finding to note here is that of the 3 groups tested, the full experimental group that was given the teaching and playing treatment of games showed the most outstanding results. Based on the Paired Sample Test table above, where the significance value is 0.00 $<0.05$, it can be claimed that $\mathrm{H} 0$ is rejected and $\mathrm{Ha}$ is accepted. Thus, it can be concluded that there is a difference in the average results of the Pre-Test and Post-Test of the experiment group, which means that there is an effect of face-to-face reading teaching combined with playing the game in improving students' reading comprehension as indicated by the post-test scores. This result provides evidence that the ArReadSpeed game when combined with teaching in the context of classroom learning produces the best learning impact. The following illustrates how the model looks like. 
Figure 3: The resulted model

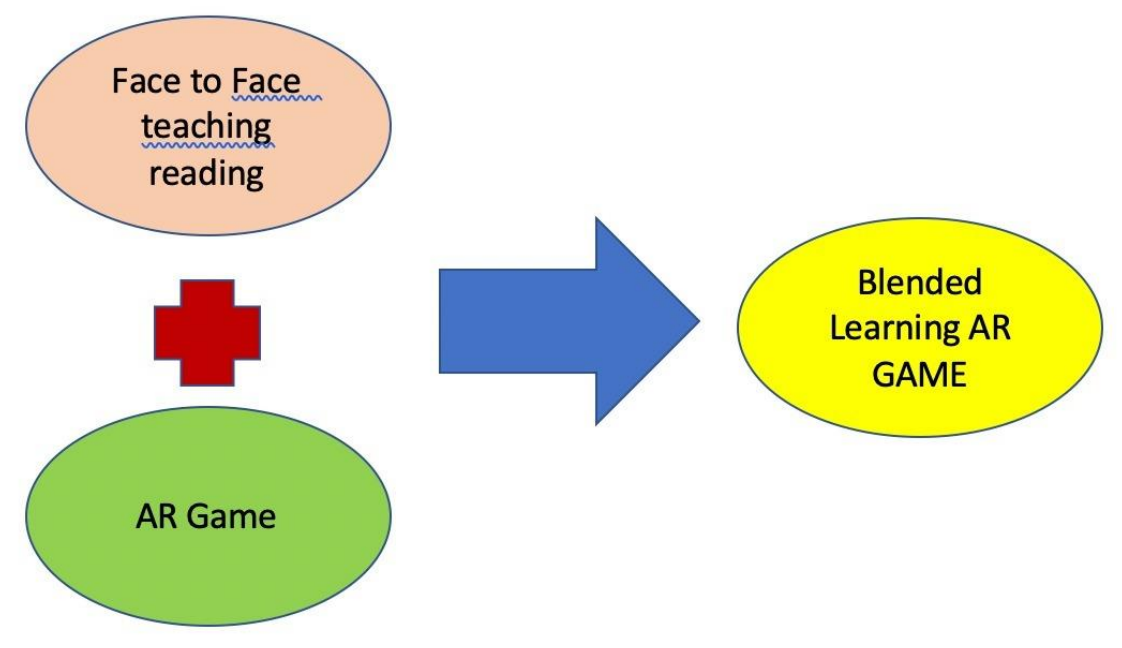

On that basis (as shown in Figure 3), the attempt to develop an AR-based to find out a blended learning model using that game found its ground and the sought model is obtained. To further substantiate the claim, other research data generated from the questionnaire and FGD are to be reported separately.

\section{Discussion and Conclusion}

Experimental results involving two control groups and an experimental group which were given different treatment and then compared statistically using a paired t-test showed that the experimental group obtained a higher mean score than the two (2) control groups. Then, a separate paired t-test comparing two control groups that were given different treatment (one group only given reading lessons, and the other group only given a game to play) proved that the group treated with a game showed different result despite being unable to determine if one is better than another. However, as the two control groups were compared with the experiment group, the latter group outperformed the two control groups which maybe because of the advantages that the game offer to the learners in creating a different learning atmosphere that is more challenging yet more fun as learning was combined in the mode of (virtual) face-to-face and game playing. In other words, this experimental study rejected the H0 suggesting that the test group which was given teaching reading to understand the content combined with playing game provide the most promising results. Thus, it can be said that as learning is put in a blended-mode, learning outcomes proved to have exceeded the one in the non-blended mode, once again, suggesting that AR-based game is proven to be compatible with the blended-learning model. The results of this experiment confirmed that the use of AR-based games for blended-learning contexts can be used as a suitable learning model to improve English reading comprehension skills. From the experimental results, it gives confidence that the game model that is designed and tested is suitable for the context of blended learning in 
secondary schools. Also, considering the fact that technology will always develop and that environment of the current and future learning is changing, this study may bring an implication for current and future education practitioners to consider incorporating games into the teaching of English skills in the context of blended learning to respond to the change in learners' styles of learning.

\section{Recommendation}

Considering the weaknesses in the process of implementing this research due to the constraints of the COVID-19 pandemic, especially the problem of the limitation of the respondent number involved in the experiment, in the future the same experimental research design is expected to consider involving a larger number of respondents with the participation of school institutions by varying public and private schools so that the conclusions of the study can be robustly drawn to represent a wider population so that the claim that AR game is suitably incorporated into the context of blended learning is more accountable.

\section{Acknowledgments}

This project was supported and funded by the DRPM Ministry of Research, Technology, and High Education, Republic of Indonesia. We would like to thank primarily the Government that has provided financial support as without it this research would not have able to materialize. We would not be able to say thanks enough to my University Rector and Dean of Faculty and everyone who have contributed to the completion of this paper.

Antonius Suratno is a lecturer at the Faculty of Language and Arts, Soegijapranata Catholic University, Semarang. His primary research interest is in the area of technology and language teaching and learning. The focus of research on which he has recently been keen on doing is the development and exploitation of mobile learning media in the context of blended learning and online learning. Email: a.surano@unika.ac.id.

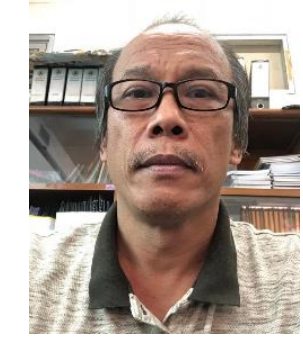

English Department, Faculty of Language and Arts, Soegijapranata, Catholic University, Semarang, Indonesia, Jl Pawiyatan Luhur IV/1, Bendan Duwur, Semarang Indonseia, 50234, a.suratno@unika.ac.id, +6282136580717 
Erdhi Widyarto Nugroho is a lecturer at the Faculty of Computer Science, Soegijapranata Catholic University, Semarang. His major research interest is in a smart system. He has recently dedicated his research endeavor in the area of the development and exploitation of game technology, interface system, and smart system.

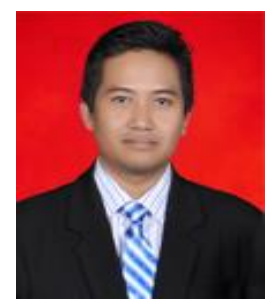

Information System Department, Faculty of Computer Science, Soegijapranata Catholic University, Semarang, Indonesia. , Jl Pawiyatan Luhur IV/1, Bendan Duwur, Semarang Indonseia, 50234, erdhi@unika.ac.id , +62 8122686327

\section{References:}

Cowan, P. and Butler, R. (2013). Making geography mobile: using location aware technology to improve student performance in physical geography. Journal of Research and Didactics in Geography, 1(2), 85-105.

Di Serio, Á., Ibáñez, M. B., and Kloos, C. D. (2012). Impact of an augmented reality system on students' motivation for a visual art course. Computers \& Education. Retrieved March, 2012, from http:// dx.doi.org/2010.1016/j.compedu.2012.2003.2002

Dunn, Opal. (1983), Beginning English with Young Children, the Macmillan Press Limited, London.

FitzGerald, Elizabeth; Ferguson, Rebecca; Adams, Anne; Gaved, Mark; Mor, Yishay and Thomas, Rhodri (2013). Augmented reality and mobile learning: the state of the art. International Journal of Mobile and Blended Learning.

Harris, C. (2009), Meet the New School Board: Board Games Are Back--And They're Exactly What Your Curriculum Needs, School Library Journal, v55 n5 p24-26

Klopfer, E. and Squire, K. (2008). Environmental detectives - The development of an augmented reality platform for environmental simulations. Educational Tech nology Research and Development, 56, 203-228. doi:10.1007/s11423-0079037-6

Kukulska-Hulme, A. and Traxler, J. (2007) Designing for mobile and wireless learning. In: Beetham, H. and Sharpe, R. (eds.), Rethinking Pedagogy for a Digital Age: Designing and Delivering E-Learning. London: Routledge, 180-192. 
Lehtinen, E. (2008). Mathematics education and learning sciences. in M.Niss(ed) ICME 10 Procedings, IMFUFA(93-104), Department of Science System and Models Roskilde University, Denmark

Lucardie, D. (2014). The impact of fun and enjoyment on adult's learning. ProcediaSocial and Behavioral Sciences, 142, 439-446.

Luckin, R. and Stanton Fraser, D. (2011). Limitless or pointless? An evaluation of augmented reality technology in the school and home. International Journal of Technology Enhanced Learning, 3(5), 510-524. doi:10.1504/IJTEL.2011.0421028.

Mark D. Griffits, Daria J. Kuss A. and Daniel L. King (2012) Video Game Addiction: Past, Present and Future, Journal of Community and Applied Social Psychology, 8, no 4

Martin-Gutierrez, J., Saorin, J. L., Contero, M., Al- caniz, M., Perez-Lopez, D. C., \& Ortega, M. (2010). Design and validation of an augmented book for spatial abilities development in engineering students. Computers \& Graphics, 34(1), 77-91. doi:10.1016/j. cag.2009.11.003

Naismith, L., Lonsdale, P., Vavoula, G. \& Sharples, M. (2004), Literature Review in Mobile Technologies and Learning. Bristol: NESTA FutureLab

Neuburger, L., Beck, J. and Egger, R. (2018), The 'Phygital' Tourist Experience: The Use of Augmented and Virtual Reality in Destination Marketing, Camilleri, M. (Ed.) Tourism Planning and Destination Marketing, Emerald Publishing Limited, pp. 183-202.

Schmalstieg, D. and Wagner, D. (2007). Experiences with handheld augmented reality. In Proceedings of the 2007 6th IEEE and ACM International Sympo- sium on Mixed and Augmented Reality (ISMAR '07).

Suratno, A. and Aydawati, E., N. (2016). Indonesian High School Students' Beliefs about the Use of Information and Communication Technology for Language Learning. International Journal of Information and Communication Technology Research (JICT). Volume 6 No. 11, November 2016

Waras. K. (2018). Pendidikan Tinggi 4.0. Artikel Opini di Harian Kompas 3 March 2018 
Appendix:

\section{SMP Mondial School, Semarang}

Appendix 1: Documentation Photos

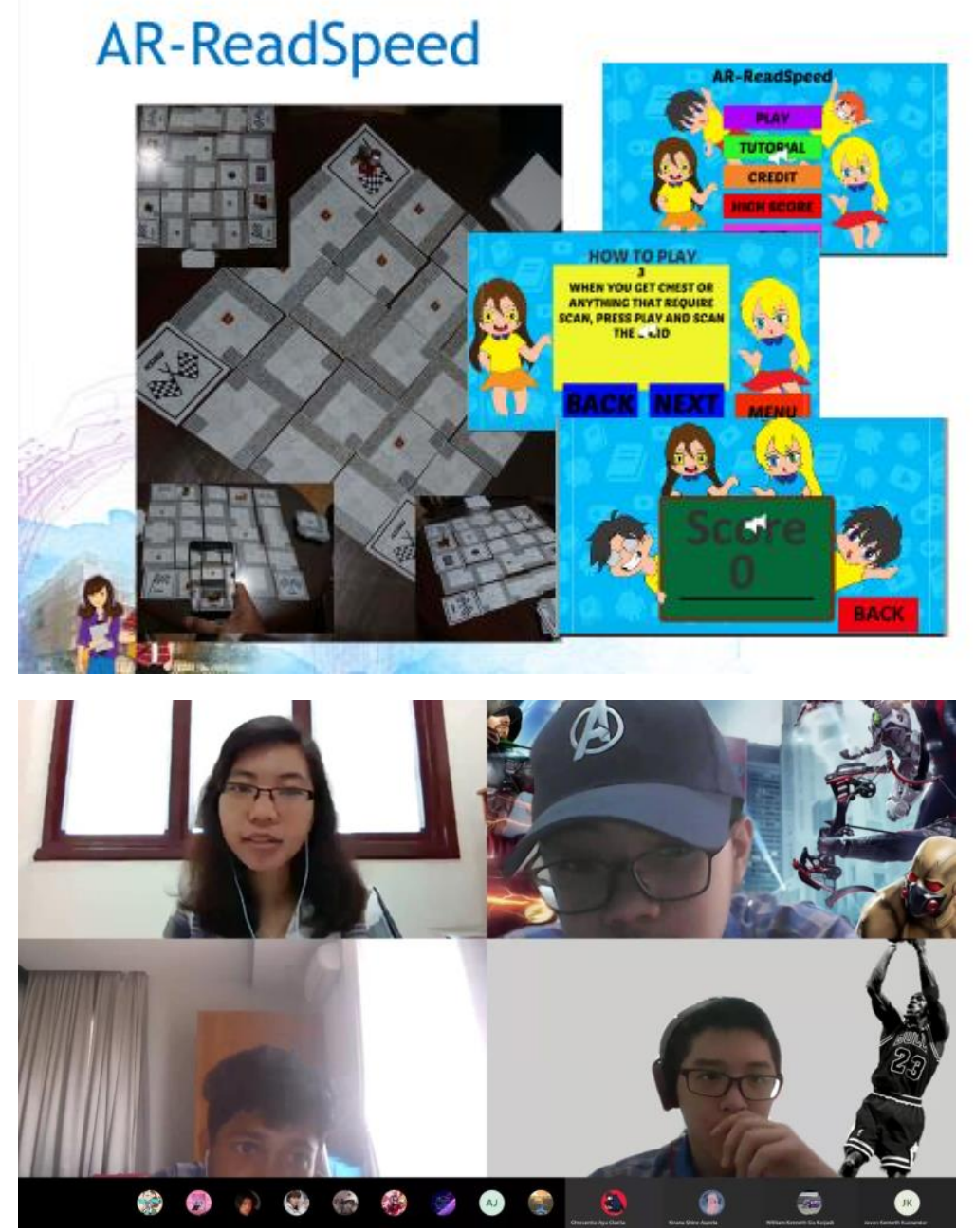




\section{SMP Pangudi Luhur Dominico Savio, Semarang}

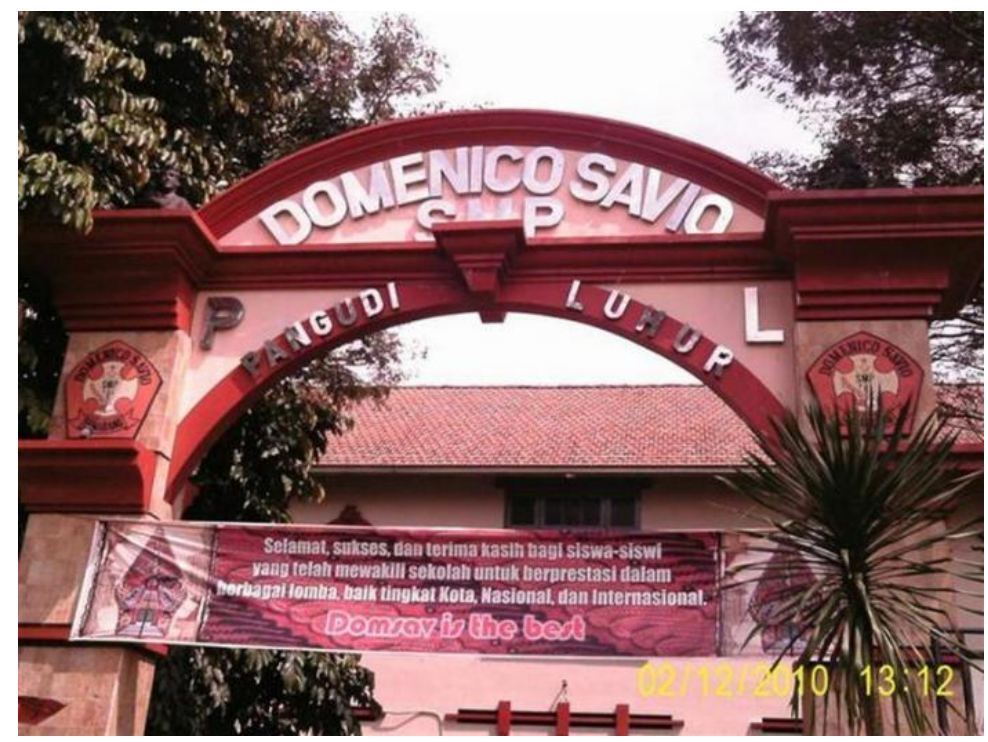

Appendix 2: Test materials

Sylvia Earle

Sylvia Earle was called a "Hero for the Planet" by Time magazine. She's an oceanographer, explorer, author, and lecturer.

Sylvia Earle is a world-famous ocean scientist and a National Geographic Explorer-inResidence. She loves diving in the ocean. She spends a lot of time under the sea. Earle has been the leader on more than a hundred expeditions. She also set a record for solo diving in 1,000metre deep water. In total, she has spent more than 7,000 hours underwater.

There are many problems in the Gulf of Mexico. But Sylvia Earle says, 'In 2003 I was in clear water in the Gulf. I was a long way from the mouth of the Mississippi River. The area was full of healthy sea life. We can protect the ocean and our future.'

Adapted from : $\underline{\text { Sylvia Earle } \mid \text { NGL Life }}$

\section{1. . Which of the sentences about Sylvia Earle is NOT true?}
A. She is a scientist.
B. She is an explorer.
C. She is a sportswoman.
D. She Is a sea diver

\section{Which place is the main focus of the article?}
A. the Gulf of Mexico
B. the Mississippi River
C. the Pacific Ocean 
D. the deep water

\section{What does Sylvia Earle like doing in the sea?}
A. Diving
B. fishing
C. swimming
D. exploring

\section{Which sentence is true?}
A. Earle has an important job at the NOAA.
B. Earle is interested in computer networks.
C. Earle wants to protect places in the sea and on the land.
D. Earle is an adventurer

\section{What does Earle say happened in the Gulf of Mexico?}
A. It was impossible to dive there.
B. Lots of animals disappeared.
C. The blue colour of the water changed.
D. Our planet can work without the ocean.

\section{What does she say about the ocean?}
A. All life on Earth needs the ocean.
B. It's an interesting place to work.
C. She feels alive in the ocean.
D. The ocean is mysterious

\section{Wild weather}

\section{What is happening to our weather?}

What is 'extreme' weather? Why are people talking about it these days? 'Extreme' weather is very unusual rain, heat, storms etc. For example, in 2010, 33 centimetres of rain fell in two days on Nashville, USA. According to weather experts, that was a 'once in 1000 years' event. But these days, extreme weather events are more frequent. Also in 2010, 28 centimetres of rain fell on Rio de Janeiro in 24 hours, and there was record rainfall in Pakistan.

Michael Oppenheimer, a climate scientist, says that we need to accept reality. Our weather is changing and we need to act to save lives and money.

Adapted from: READING COMPREHENSION with Listenings - English Almería by Alcaina (google.com) 


\section{The article says that extreme weather is ...}
A. more common nowadays.
B. not natural.
C. more unusual in the USA.
D. anomalous

\section{Examples of extreme weather include ...}
A. warm, wet air.
B. El Niño and La Niña.
C. very hot weather in Europe.
D. prolonged rain

9. One cause of extreme weather is ...
A. floods across large areas.
B. very hot summers.
C. Very cold winter
D. water vapour in the atmosphere.

10. What happened after the extreme rain in Rio de Janeiro?
A. There were big floods.
B. There were many deaths.
C. Millions of people were affected.
D. Many people lost their homes

11. The article says that extreme weather events are the result of ...
A. natural cycles.
B. human activity.
C. natural cycles and human activity.
D. natural disaster

12. What is happening to the oceans?
A. They are getting bigger.
B. They are getting hotter.
C. They are producing greenhouse gases.
D. They are getting colder 


\section{Appendix 3: Screenshot of SPSS}

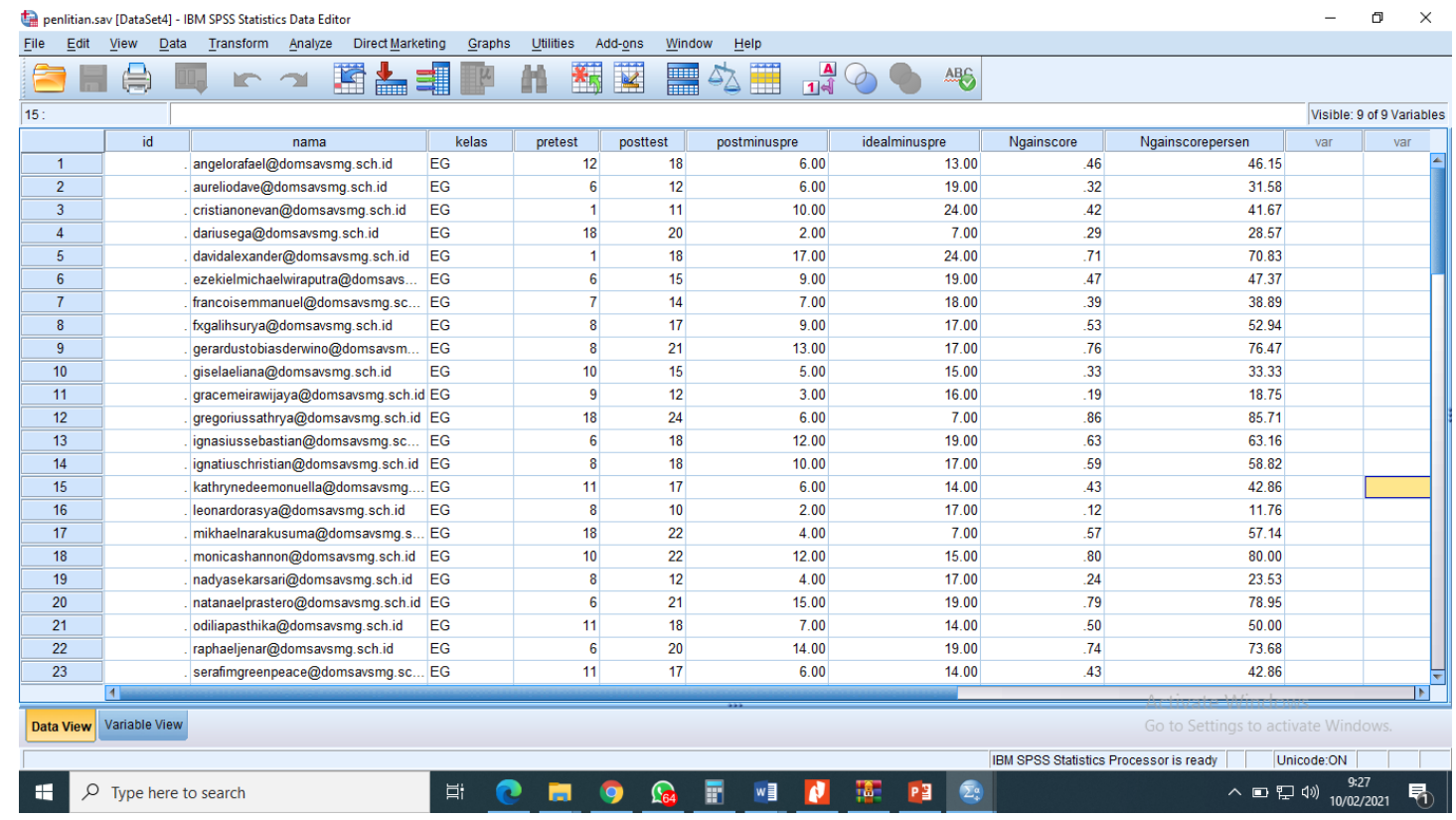

TA. Output-3 groupttest.spv [Document5] - IBM SPSS Statistics Viewer

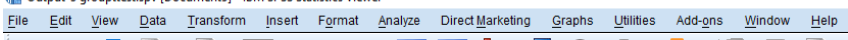

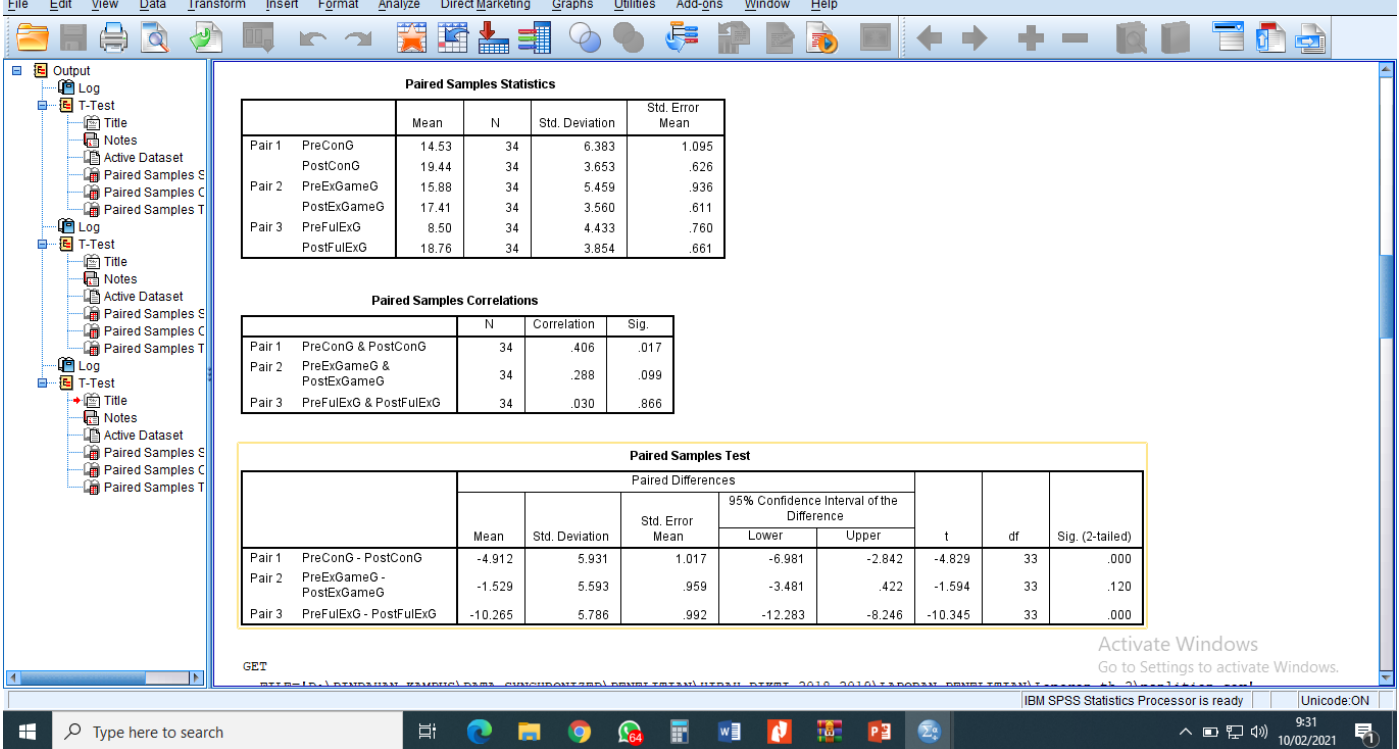

